\title{
冬季の避難所を想定した睡眠環境が人の生理反応に及ぼす影響に関する研究 A STUDY TO EXAMINE THE THERMAL ENVIRONMENT ON SLEEP AND PHYSIOLOGICAL RESPONSES IN SHELTER-ANALOGUE SETTINGS IN WINTER
}

\author{
望月要佑*1, 前田和毅*1, 都築和 代*2, 鍋島佑 基*3 \\ Yosuke MOCHIZUKI, Kazuki MAEDA, Kazuyo TSUZUKI \\ and Yuki NABESHIMA
}

\begin{abstract}
The aim of this study was to investigate sleep in evacuation shelter-analogue settings in winter using disaster relief blankets and ordinary futons. Subject experiments were conducted to examine the sleep variables using actigraphy and the environmental conditions in a gymnasium during winter. The Sleep Efficiency Index and sleeping time decreased significantly in the first night when using disaster blankets. The mean skin temperature was significantly lower for sleeping times using disaster blankets. However, no significant difference in rectal temperature was found between the blankets and a pair of futons.
\end{abstract}

Keywords: Evacuation facilities, Winter, Sleep, Thermal environment, Thermoregulation 避難所，冬季，睡眠，温熱環境，体温調節

\section{1.はじめに}

近年、東日本大震災や熊本震災など多くの大規模災害が発生し、 避難所での生活に注目が集まっている。避難所は、近隣地域の体育 館や公民館など公共施設が開放され、仮設住宅などへ入居するまで の仮住まいとして利用される。しかし、それらの施設は居住用では ないため、誰もが安心して暮らせる生活環境が提供されるとは限ら ず、避難者の健康を損なう可能性もあると考えられる ${ }^{1), 2) 。 ~}$

避難所の温熱環境や二酸化炭素濃度等の実態については、既往研 究 1), 3), 4)で報告されている。冬季の場合、夜間の体育館内室温は $5^{\circ} \mathrm{C}$ 前後 ${ }^{4}$ まで低下し、低温な環境であることが確認されている。 また、避難所に備蓄されている備蓄品数 ${ }^{4}$ は、災害救助用毛布が避 難所一ヶ所当たり 12.3 枚、ストーブが避難所一ヶ所あたり 0.1 台と 極めて少なく、これらのことから、避難所が必ずしも快適な環境で はないことが容易に推測される。

人は夜間に良質な睡眠をとるか否かで、日中の生活の質が大きく 変わってくる。そのため、被災者の精神衛生や復興の観点から、良 質な睡眠を取ることできる環境が提供されることが望ましい。しか しながら、避難所の低温環境下で人が生活し、そこで睡眠した場合 の人体一の影響を明らかにした研究は見当たらず、現在までに行わ れている研究や報告では、寝具の断熱性など温熱性能が示さていな いため、避難所への問題提起や結果に統一性が認められない。

現在まで多くの夏季についての睡眠環境研究が実施されている。 しかし、冬季環境下での睡眠については、寝具の影響も含め、低温 環境に暴露された状態での睡眠の実態はほとんど解明されていない。 そのため、本研究では冬季に本学の体育館内武道場にて、避難所
を想定した睡眠環境と通常寝具による睡眠環境の 2 条件を設定し、 寒冷環境下の避難所で人が睡眠した際の生理反応への影響を明らか にすることを目的として被験者実験を実施した。

\section{2. 研究方法}

\section{1 概要}

本研究では、豊橋技術科学大学の体育館 2 階武道場にて避難所を 想定した睡眠環境を設営し、被験者実験を行う。その際の温熱環境 の実態と被験者の睡眠や睡眠時の体温調節に関わる生理反応を測定 し、その関係を明らかにする。被験者には、豊橋技術科学大学の男 子大学院生で睡眠に問題を持たない健康な 12 名（平均 23.1 歳 $\pm \mathrm{SD}$ 0.3）を採用した。全被験者が自宅での通常時睡眠調査の際には、睡 眠効率が $90 \%$ 以上(内 10 名が $98 \%$ 以上)であり、極端な夜型生活リズ ムでないことを確認している。実験は 2017 年の 1 月〜2 月に実施し た。

\section{2 実験条件と手順}

被験者の服装は、上半身：インナーシャツ、トレーナー、パーカ 一、下半身：下着、スウェットパンッ、ジャージに統一 (0.76 clo) した。就寝環境は、避難時を想定して本学内災害救助倉庫に備蓄さ れている $2 \mathrm{~m} \times 2 \mathrm{~m} \times 1 \mathrm{~m}$ の段ボール製パーティションと災害救助用毛 布 4 枚（敷 1 枚、掛 3 枚）を使用して就寝する毛布条件（以下、毛 布と記し、図表中では Blankets と記す）と、普通の一組の布団（敷 布団 1 枚、掛布団 1 枚）を使用して就寝する布団条件 (同様に、以 下、布団と記し、図表中では Futon と記す) の計 2 条件を設定した。

\footnotetext{
*1 豊橋技術科学大学建築・都市システム学専攻 大学院生

*2 豊橋技術科学大学建築・都市システム学系 教授・博士 (学術)

*3 豊橋技術科学大学建築・都市システム学系 助教・博士(工学)
}

Grad. Student, Dept. of Arch. And Civil Eng., Toyohashi Univ. of Tech. Prof., Dept. of Arch. And Civil Eng., Toyohashi Univ. of Tech., Ph.D.

Assist. Prof., Dept. of Arch. And Civil Eng., Toyohashi Univ. of Tech., Dr.Eng. 
また、布団条件では段ボール製パーティションは使用せず、災害用 寝具（毛布条件）での睡眠と通常寝具(布団条件)での睡眠の比較を 行った。使用した寝具の諸元とサーマルマネキンによる断熱性の測 定結果を Table 1 に示す。また、Table 1 の clo 值については、各条件 で使用する寝具をすべて（毛布：敷 1 枚、掛 3 枚、布団：敷 1 枚、 掛 1 枚）使用した際の clo 值となっている。使用した災害救助用毛 布（以下、毛布と呼称）の就寝環境を Fig.1 に、布団の就寝環境を Fig.2 に示す。

被験者は 1 人当たり布団と毛布の 2 条件をそれぞれ 1 回ずつ参加 する。測定は 1 晚につき 4 人 (毛布: 2 人、布団 $: 2$ 人) 同時に行い、 計 6 日（延 24 人）行った。実験データに偏りがないよう、第一夜目 を毛布から 6 人、布団から 6 人と統制して実験を行った。また、実 験を行った 6 日間の天候については全日晴れであった。

実験を行った武道場は北面、東面が全面、南面の一部が外気と接 している構造となっている。窓については、北面、東面の上部と下 部に小空が設けられており、南面の一部に引き戸が設けられている。 武道場内の全景を Fig.3 に示す。

被験者は実験夜に $22: 30$ に武道場に集合し、各種センサーを装着 し、その後、23:45 まで各就寝環境にて安静をとった。23:45より アンケートの記入を行い、24:00に消灯し、翌朝 7:00 までの計 7 時間の睡眠を被験者はとった。実験夜の前の行動については、日中 は普段通りに授業やサークル活動、アルバイト等を許可し、入浴、 食事については被験者の自由とした。その際、睡眠に障害をきたす ため、実験夜の飲酒は禁止とした。また、消灯後の活動については、 携帯電話等の電子機器の使用の一切を禁止し、被験者間の会話等も 禁止した。

\section{3 温熱環境及び生理測定}

環境側測定項目の詳細を Table 2 に、生理測定項目の詳細を Table 3 に示す。温熱環境の測定項目については、外気の温湿度、各就寝環 境の頭部付近と足元付近の温湿度、寝床内気候を 30 秒間隔で測定し た。足元付近の温湿度測定の結果は、頭部付近の温湿度とほとんど 差がなかったため、本稿では頭部付近の温湿度を室内温熱環境とし て扱う。寝床内気候は、掛布団や毛布の内側の腰部分で測定を行っ た。生理測定項目については、皮膚温 7 点 (前額、胸部、上腕、大 腿、下腿、足背、背中)、直腸温、心拍、活動量の測定を行った。皮 膚温については皮膚温センサーを各部位にサージカルテープを用い て貼付し、直腸温については直腸温センサーに使い捨てのゴムカバ 一で被覆し、その上にワセリンを塗布して、約 $10 \mathrm{~cm}$ 肛門から直腸 に挿入し留め置いた。活動量はアクチグラフ 5), 注 1) によって測定を 行い、Cole らのアルゴリズム ${ }^{5}$ による解析ソフト AW2 を使用し、睡 眠効率(Sleep Efficiency Index, SEI)、中途覚醒回数(Wakefulness(N))、 中途覚醒時間(Wakefulness(min))、入眠潜時(Sleep Onset Latency, SOL)、

Table 1 Bedding specifications

\begin{tabular}{|c|c|c|c|}
\hline & \multicolumn{2}{|c|}{ Futon } & \multirow{2}{*}{ Blankets } \\
\hline & quilt & matress & \\
\hline Size $(\mathrm{mm})$ & $1550 \times 2100$ & $1100 \times 2200$ & $1400 \times 2000$ \\
\hline Weight (kg) & 2.1 & 2.7 & 1.4 \\
\hline Material & \multicolumn{2}{|c|}{ Polyester $100 \%$} & Polyester $100 \%$ \\
\hline Number & 1 & 1 & 4 \\
\hline Clo valua (clo) & \multicolumn{2}{|c|}{3.1} & 1.3 \\
\hline
\end{tabular}
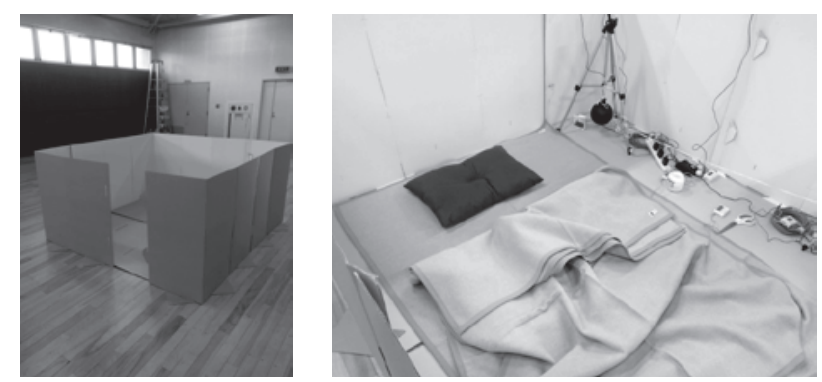

Fig. 1 Case-Blankets
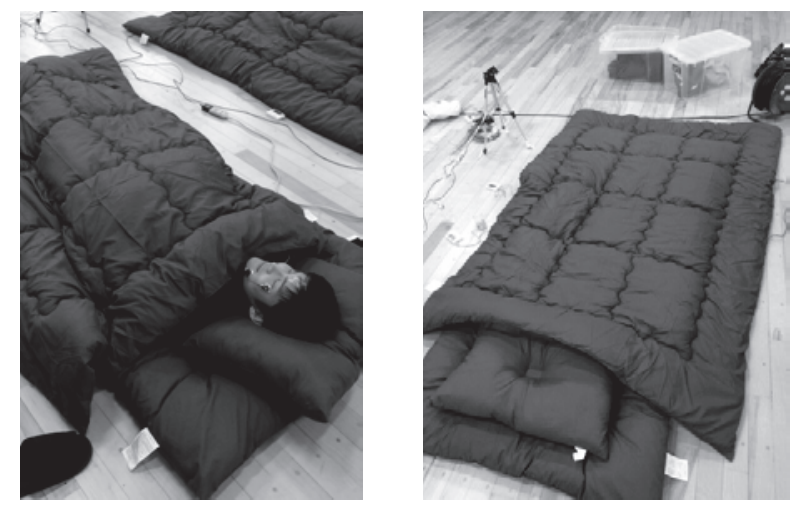

Fig. 2 Case-Futon

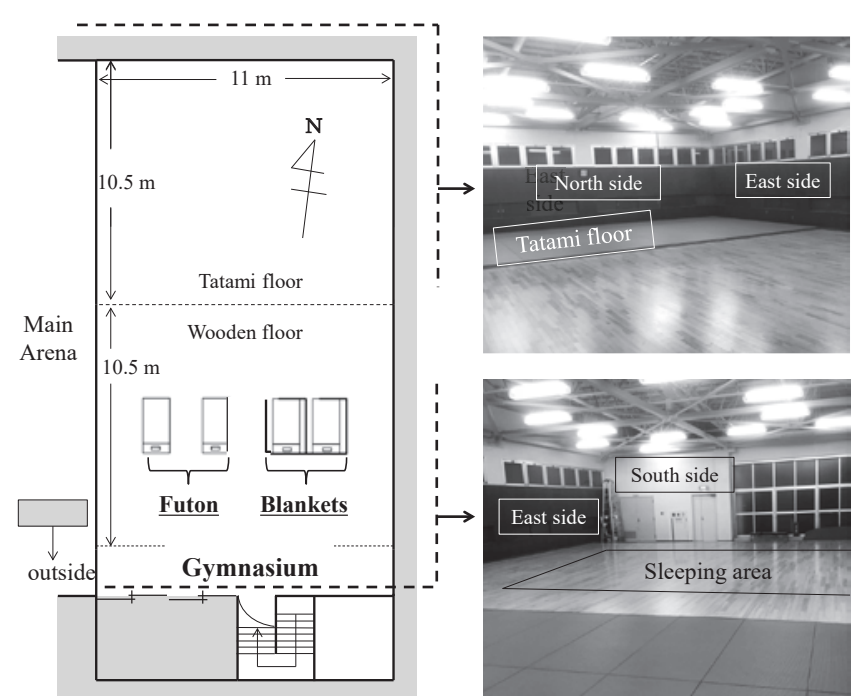

Fig. 3 Gymnasium floor plan

Table 2 Environmental measurements

\begin{tabular}{|c|c|c|c|c|c|}
\hline Mesure & ments items & Measuring equipment & Precision & Points & Interval \\
\hline \multirow{3}{*}{$\begin{array}{l}\text { Air Temp } \\
\left({ }^{\circ} \mathrm{C}\right)\end{array}$} & Indoor & T type Thermocouple & \multirow{3}{*}{ $\pm 0.5^{\circ} \mathrm{C}$} & Near the head, Foot & \multirow{3}{*}{$\begin{array}{c}30 \\
\text { seconds }\end{array}$} \\
\hline & $\begin{array}{l}\text { Bedding } \\
\text { microclimate }\end{array}$ & Thermistor thermometer & & 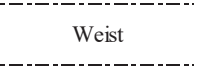 & \\
\hline & Outdoor & $\begin{array}{l}\text { T type Thermocouple } \\
\text { Thermistor thermometer }\end{array}$ & & Outdoor & \\
\hline RH (\%) & $\begin{array}{c}\text { Indoor } \\
\text { Microclimate } \\
\text { Outdoor }\end{array}$ & $\begin{array}{l}\text { Polymer membrane resistance } \\
\text { type hygrometer }\end{array}$ & $\pm 5 \%$ & $\begin{array}{c}\text { Near the head, Foot } \\
\text { Weist } \\
\text { Outdoor }\end{array}$ & $\begin{array}{c}30 \\
\text { seconds }\end{array}$ \\
\hline
\end{tabular}

Table 3 Physiological measurements

\begin{tabular}{|c|c|c|c|c|}
\hline Mesurements items & Measuring equipment & Precision & Points & Interval \\
\hline \multirow{2}{*}{$\begin{array}{l}\text { Skin temperature } \\
\text { Rectal temperature } \\
\text { Sleep variables }\end{array}$} & Thermistor thermometer & $\pm 0.5^{\circ} \mathrm{C}$ & $\begin{array}{l}7 \text { point } \\
\text { Rectal }\end{array}$ & 30 \\
\hline & Watch Type Activity Meter & & Non-dominant hand & seconds \\
\hline Heart rate & Heart rate monitor & $\begin{array}{c}0.001 \\
\text { seconds }\end{array}$ & Chest 3 point & $1 \mathrm{kHz}$ \\
\hline
\end{tabular}


睡眠時間(Sleep time)などの睡眠変数の算出を行った。睡眠効率は、 以下の式(1)によって算出を行う。

$$
\operatorname{SEI}(\%)=\frac{\text { Sleep time }}{(\text { Sleep time }+ \text { Wakefulness period time })} \times 100
$$

また、Hardy\&DuBois の 7 点法の変法注2)を使用し、測定した皮膚 温から平均皮膚温 Tsk 算出した。2 種類の寝具によって形成され る睡眠環境の影響を比較するために、二元配置分散分析（2-ANOVA (条件 $\times$ 時間)）によって睡眠変数や皮膚温、直腸温、心拍数および 寝床内気候を評価した。

就寝中の音環境の測定は、被験者の近傍で騒音計を用いて 10 秒間 隔で測定した。

\section{3. 結果と考察}

\section{1 武道場内外の温湿度および寝床内気候}

実験を行った 6 日間の夜 0 時から翌 7 時までの頭部付近および外 気温の平均值と最大最小值を Fig.4 に、実験中の外気と頭部付近の 気温と相対湿度の平均值の時間変動を Fig. 5 に、寝床内気候の温度 と相対湿度の平均值の時間変動を Fig.6 に示す。

Fig.4 から、全実験日おいて頭部付近温度が $8^{\circ} \mathrm{C}$ 以下となっている ことから、武道場内がかなり低温な環境であったことが確認できる。 実験を行った 6 日間の天候については全日晴れであった。Fig.5 では 就寝開始時の室内平均気温は約 $5.9^{\circ} \mathrm{C}$ 、明け方は約 $3.6^{\circ} \mathrm{C}$ と $2^{\circ} \mathrm{C}$ 程度 低下しているが、室内湿度は 53\%前後で安定している。また、Fig.4 の全日程の各温度については、Fig.5 の時間変動と同様の変化をして おり、図中の Max が消灯時、Min が明け方の結果となっている。既 往の冬季体育館内の温熱環境調查 $\left.{ }^{6}\right)$ では、夜間の外気温が $0^{\circ} \mathrm{C}$ 付近 で安定している場合、体育館内温度は明け方で $6^{\circ} \mathrm{C}$ 以下となること が報告されているため、特別な断熱措置が施されていない冬季体育 館内は非常に寒冷な温熱環境になることが確認できた。また、布団 と毛布でそれぞれ就寝時の頭部付近の気温の変動は、約 $0.1^{\circ} \mathrm{C}$ とほ ぼ差を認めない。このことから段ボール製パーティションによる就 寝環境の熱的な改善はほとんどないと考えられ、毛布と布団の両条 件において、ほぼ同一睡眠温熱環境であったことが確認できた。

Fig.6より毛布と布団の平均寝床内気候の時間変動を比較すると、 消灯後、布団では寝床内温度が $3: 00$ 付近まで上昇しているのに対 し、毛布では 1:30 頃からほぼ一定で推移しており、相対的に毛布 の方が低温となっていることが確認できる。平均寝床内温度は毛布 が 22.2（SD $\pm 1.7 ）{ }^{\circ} \mathrm{C}$ 、布団が 23.8（SD $\pm 1.7 ）{ }^{\circ} \mathrm{C}$ となり、毛布が $1.6^{\circ} \mathrm{C}$ 低い温度になることが確認できた。平均寝床内湿度についても、 毛布が 33.8 （SD $\pm 2.8 ） \%$ 、布団が $37.7 （ \mathrm{SD} \pm 2.0$ ）\%となり、 毛布の方が低い結果となった。これらの結果は Table 1 に示すように、 両寝具の断熱性能が異なり、毛布の方が clo 值が低いため、寝床内 気候も毛布の方が低い值となったと考えられる。既往研究 7) では、 同一の寝具を使用して $3^{\circ} \mathrm{C} 、 10^{\circ} \mathrm{C}$ おび $17^{\circ} \mathrm{C}$ の環境下での就寝時、 寝床内温度はほぼ同一の温度で変動を示していた。本研究との違い は、既報は寝具の clo 值が高かったためと考えられるが、本研究で は使用する寝具により形成される寝床内気候が大きく異なった。以 上の clo 值および寝床内気候の結果から、本研究で用いた毛布は布

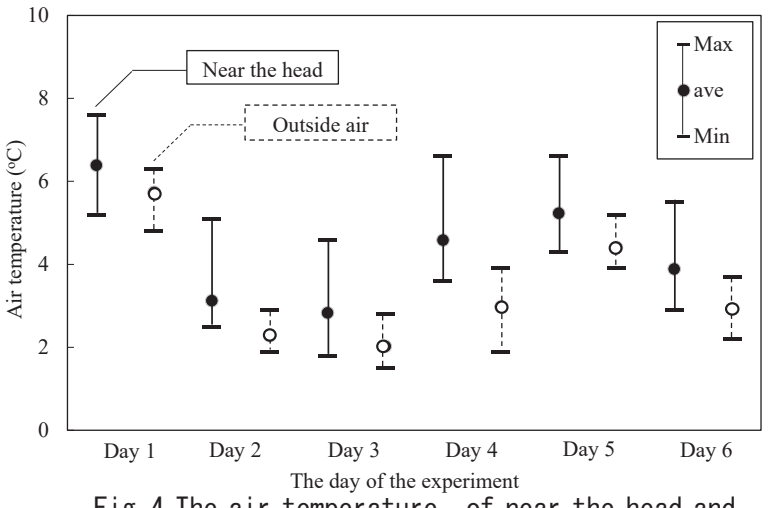

Fig. 4 The air temperature of near the head and outside air

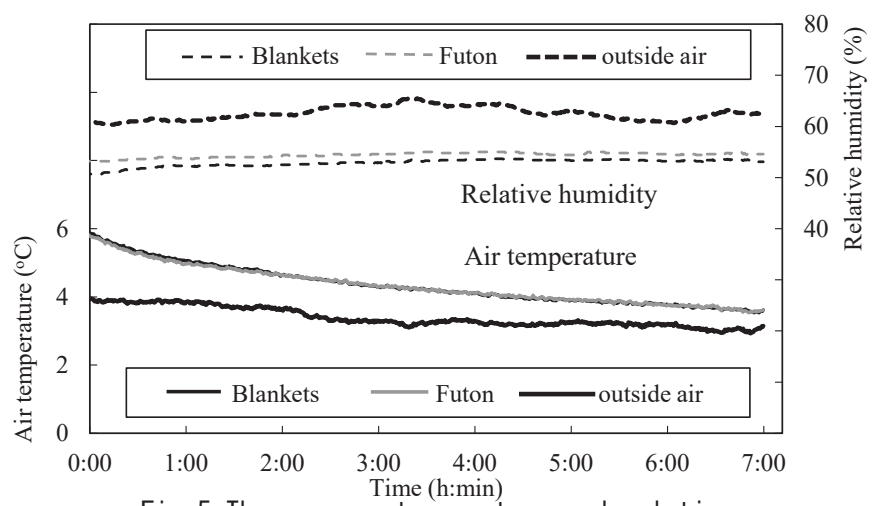

Fig. 5 The average temperature and relative humidity around the subject' $s$ head in each case

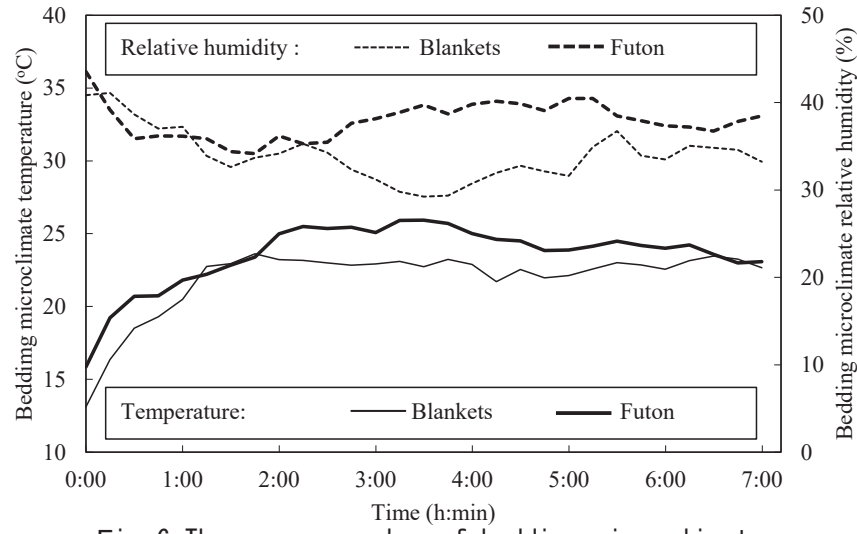

Fig. 6 The average value of bedding microclimate

(temperature and humidity) at 15 minute intervals

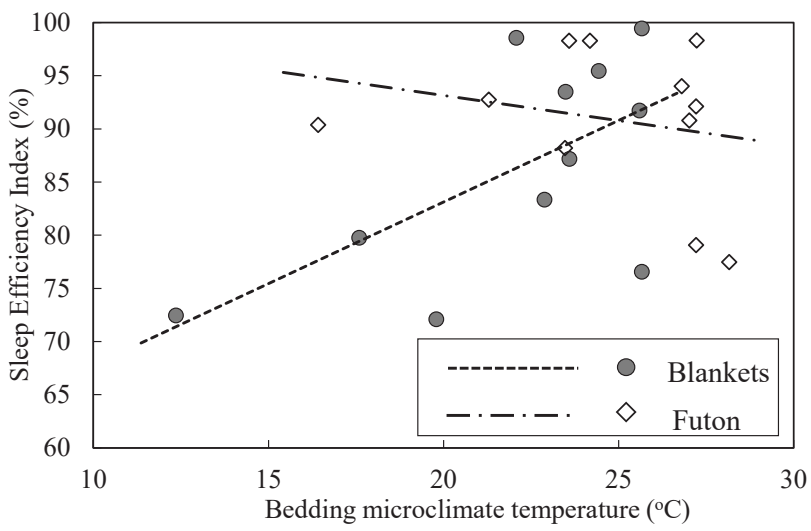

Fig. 7 Relationship between SEI and bedding microclimate 
団よりも、周囲環境からの断熱特性および寝床内の保温性能が劣っ ていたことが確認できる。

音環境については、平均 $32 \mathrm{~dB} （ \mathrm{SD} \pm 1.9 \mathrm{~dB}$ 、最大 $41.5 \mathrm{~dB}$ ）であ り、睡眠への影響は無かったと考えられた。

\section{2 睡眠変数への影響}

布団と毛布の両条件における睡眠変数の結果を平均值 $\pm \mathrm{SD}$ と $\mathrm{p}$ 值 で Table 4 注3)に示す。Table 4 では睡眠効率は毛布で約 $86 \%$ 、布団で 約 $91 \%$ となり、毛布の方が睡眠効率は低くなったが、統計的に有意 な差は認められなかった。また、中途覚醒回数や中途覚醒時間など では毛布の方が高い值となったため、毛布を使った睡眠変数は布団 使用時よりも劣っていたと推察される。しかし、各睡眠変数の分散 が大きいため、布団使用時と毛布使用時との間に有意な差は確認で きなかった。既往の低温環境下での睡眠研究 ${ }^{8)}$ では、室温 $3^{\circ} \mathrm{C}$ 程度 の低温環境下の睡眠でも、睡眠効率が約 $94 \%$ と比較的高い睡眠効率 が維持できていた。これは寝具の断熱性能が高く、比較的快適な寝 床内気候が形成されていたため、低温環境下でも高い睡眠効率を維 持できたと考えられ、本研究のように低温環境下で毛布のような寝 具の断熱性能が低く、低温な寝床内気候を形成する寝具を使用した 場合に、睡眠を悪化させる可能性が示唆された。しかし、Fig.7 に示 すように、寝床内温度と睡眠効率の関係が毛布と布団では傾向が異 なるため、低温環境下での睡眠は、単に高い寝床内温度を維持する ことだけでは良質な睡眠がとれない可能性があると考えられる。ま た、毛布においても睡眠効率が高い被験者も存在することから、被 験者個人の普段の睡眠習慣や不慣れな環境への適応能力の違いが大 きく関わってきているのではないかと推察される。

次に、緊急避難時を想定し、最も影響を受けやすいと考えられる 第一夜目の結果について布団と毛布についての比較を行う。第一夜 目の各睡眠変数の平均值 $\pm \mathrm{SD}$ と $\mathrm{p}$ 值を Table 5 に示す。毛布の方が、 睡眠効率、睡眠時間において有意水準 $5 \%$ で有意に低くなり、中途 覚醒時間は有意に増加した。また、入眠潜時を除く全ての睡眠変数 において有意水準 $10 \%$ で毛布の方が悪い結果となり、布団のほうが 良好な睡眠が取れている結果となった。

既往研究 9)では、東日本大震災発生時、睡眠時間などが震災前夜 と比較し、有意に悪化したという結果が報告されている。この場合 は災害による心的ストレスの影響が考えられるが、それらが除かれ ている本研究のような場合においても、また、睡眠に障害のない健

Table 4 Sleep variables (mean $\pm S D$ )

\begin{tabular}{lccc}
\hline & Blankets $(\mathrm{n}=11)$ & Futon $(\mathrm{n}=12)$ & p-value \\
\hline SEI (\%) & $86.4 \pm 10.1$ & $91.2 \pm 6.9$ & 0.200 \\
Wakefulness (N) & $20.3 \pm 9.6$ & $15.1 \pm 7.9$ & 0.169 \\
Wakefulness (min) & $69.9 \pm 39.4$ & $50.0 \pm 32.7$ & 0.206 \\
SOL (min) & $18.0 \pm 20.1$ & $16.0 \pm 10.1$ & 0.771 \\
Sleeping time (min) & $348.4 \pm 40.4$ & $368.3 \pm 32.4$ & 0.209 \\
\hline
\end{tabular}

Table 5 Sleep variables of first night (mean \pm SD)

\begin{tabular}{lrrc}
\hline & Blankets $(\mathrm{n}=6)$ & \multicolumn{1}{c}{ Futon $(\mathrm{n}=6)$} & p-value \\
\hline SEI (\%) & $84.6 \pm 8.0$ & $93.9 \pm 4.1$ & 0.029 \\
Wakefulness (N) & $22.1 \pm 9.4$ & $12.3 \pm 6.3$ & 0.061 \\
Wakefulness (min) & $75.8 \pm 34.7$ & $36.0 \pm 18.4$ & 0.032 \\
SOL (min) & $18.7 \pm 19.6$ & $14.5 \pm 13.7$ & 0.678 \\
Sleeping time (min) & $342.5 \pm 38.3$ & $382.3 \pm 18.5$ & 0.045 \\
\hline
\end{tabular}

康な青年男子であったとしても、緊急避難時に使用される寝具を使 用しての低温環境下での就寝は、睡眠が悪化する可能性があること が明らかになった。

\section{3 皮膚温および直腸温}

毛布と布団の両条件における前額皮膚温、足背皮膚温、平均皮膚 温、直腸温を 15 分間隔で平均した時間変動の結果を Fig. 8 に示す。 前額については、両条件とも消灯後に一時的に上昇するが、その 後、約 $29^{\circ} \mathrm{C}$ 前後で翌 $7: 00$ まで比較的安定した温度であった。足背 については、両条件間に大きな差が見られ、毛布で翌 $7: 00$ まで低 下し続けていた。一方、布団については、約 $28^{\circ} \mathrm{C}$ 程度で安定してい る。平均皮膚温は、消灯後、徐々に上昇し、1：00 頃から毛布では 約 $32^{\circ} \mathrm{C}$ 、布団が約 $33^{\circ} \mathrm{C}$ で安定、その後、徐々に低下している。ま た、全時間帯で布団が毛布より高くなる結果となり、2つの条件間 に有意水準 5\%の有意差が確認された。先に述べた寝床内気候の結 果をみても、両条件間に $1.6^{\circ} \mathrm{C}$ の差があることや、clo 值に大きな差 があるため、毛布では低温な寝床内気候しか形成できず、平均皮膚 温は有意に低下したと考えられる。また、既往研究 ${ }^{10}$ お小いて、足背 や手背皮膚温の変動が著しく、足背に至っては起床まで低下し続け ることも報告されており、就寝前において未梢部皮膚温が著しく低 い場合、入眠潜時が長くなるなどの報告がなされている ${ }^{11)}$ 。今回、 睡眠中の末梢部皮膚温低下が著しいことから、今後主観申告との関 係等について検討していきたい。

寝床内気候とは人体からの放熱が寝具によって遮られて作られた 寝具と人体との間のすき間の温湿度等を指す。寝床内気候に両条件 間で有意な差はないが、わずかに布団の方が寝床内温度は高く、ま た、今回は測定できなかったが、人体と寝具との密着性には違いが あると考えられる。寝具と人体との密着性が低いために、寝床内空 間が形成され、そのために人体からの放熱が拡散し、寝床内温度が 低下寸ることよって、いっそう未梢部皮膚温が低下した可能性があ ると推察される。これらのことから、寝具の断熱性能だけでなく、 寝具の柔軟性・密着性など寝具と身体との適合度などについて検討 が必要であろう。

直腸温については、両条件の時間変動にほぼ差はなく、消灯から 起床にかけて $2^{\circ} \mathrm{C}$ 程度の温度低下が確認でき、明け方で $35.7^{\circ} \mathrm{C}$ 前後 まで低下している。今回の直腸温の低下は、低体温症のひとつの目 安である $35^{\circ} \mathrm{C}$ 付近まで低下しているため、布団のような通常寝具で あっても、冬季避難所内での就寝環境の工夫および改善が必要であ ると考えられる。また、布団を使用寸る際に首以下の部分を布団に より覆うことが一般的である。唯一環境に直接暴露されている部位 である頭部が周囲の低温環境に暴露されていることから直接経皮冷 却され、また、呼吸時の給気を通じて気道が冷却されることが、体 内温である直腸温の低下に関係していると既往研究 7)では示唆して いる。本研究では、それぞれの実験日に各条件 2 名ずつがほぼ同一 の温熱環境下で睡眠実験を行ったため、各被験者で頭部冷却におけ る体内温への影響がほぼ同じであったと考えられる。よって、前額 皮膚温と体内温である直腸温の変動については、使用寸る寝具の差 ではなく、就寝する温熱環境に依存している可能性が示唆された。

森らの既往研究 ${ }^{10)}$ では、室温 $4^{\circ} \mathrm{C}$ 程度の環境下での睡眠中、平均 皮膚温が $30^{\circ} \mathrm{C}$ から $32^{\circ} \mathrm{C}$ 程度で推移していることを示しており、本 

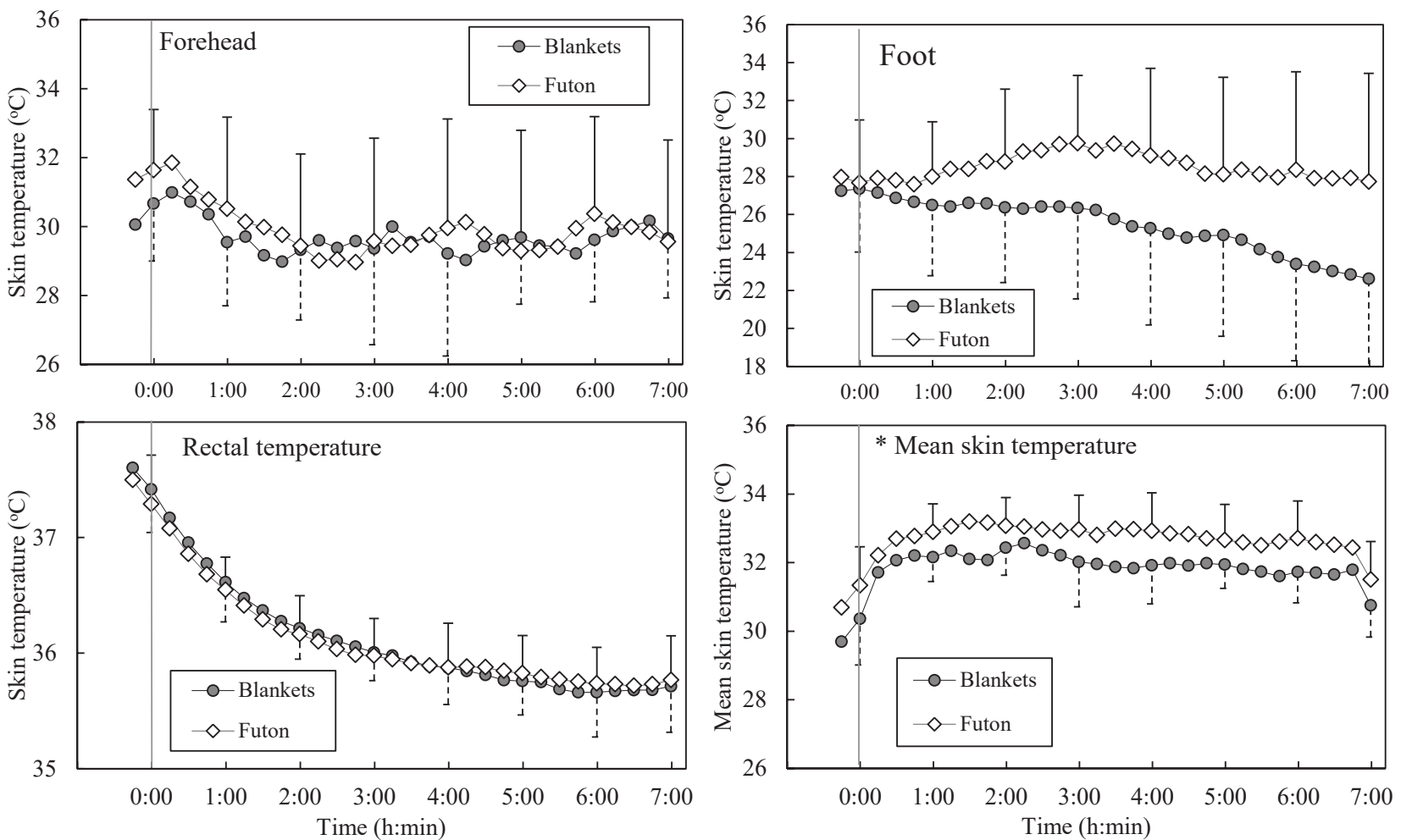

Fig. 8 Results of averaging the skin temperature (forehead, instep), mean skin temperature and rectal temperature at 15-minute intervals. The vertical I ine indicates standard deviation. The $*$ indicates significant effect of condition by at least $\mathrm{P}<0.05$

研究の平均皮膚温の結果は妥当性があると考えられる。しかし、既 報では寝具等についての詳細な情報については言及されていないた め、本研究においての結果は、寝具および温熱環境の影響を踏まえ た今後の避難所運営および低温環境下での就寝に対する具体的な指 標となりうると考えられる。しかし、各部位皮膚温や直腸温につい ては有意な差を確認することが出来なかった。

以上の結果から、今回使用した毛布のような寝具の断熱性能が低 く、低温な寝床内気候を形成する寝具を使用し、低温環境下で就寝 することは、末梢部皮膚温を低下させ、平均皮膚温度を有意に低下 させる傾向が確認された。今後の冬季の避難所等における寝具の必 要要件を示すことができたと考えられる。

\section{4 心拍数および LF/HF}

毛布と布団の両条件の心拍数と LF/HF を 15 分間隔で平均した時 間変動を Fig.9、Fig.10 に示す。

Fig.9 では心拍数は消灯前に比心、消灯後は $0: 45$ まで著しく低下 し、その後は起床前まで徐々に低下している。両条件の心拍数はほ ぼ同じ変動を示し、平均值に有意な差は認められなかったことから、 寝具を使った低温環境下での睡眠による心拍数への影響は小さいも のと考えられる。Fig.10 に示す LF/HF の時間変動は、消灯後、一時 的に低下寸るが、時間経過につれ徐々に上昇する傾向が確認できた。 入眠時の LF/HF が高い理由は、被験者がセンサーの装着のために直 前まで活動していたことが原因と考えられる。その後、翌朝 7:00 まで両条件ともに徐々に上昇しているのが確認できる。また、毛布 に関しては、LF/HF の変動が比較的大きいため、よりストレスを感 じていると考えられる。さらに、一晚の LF/HF の平均值は毛布が

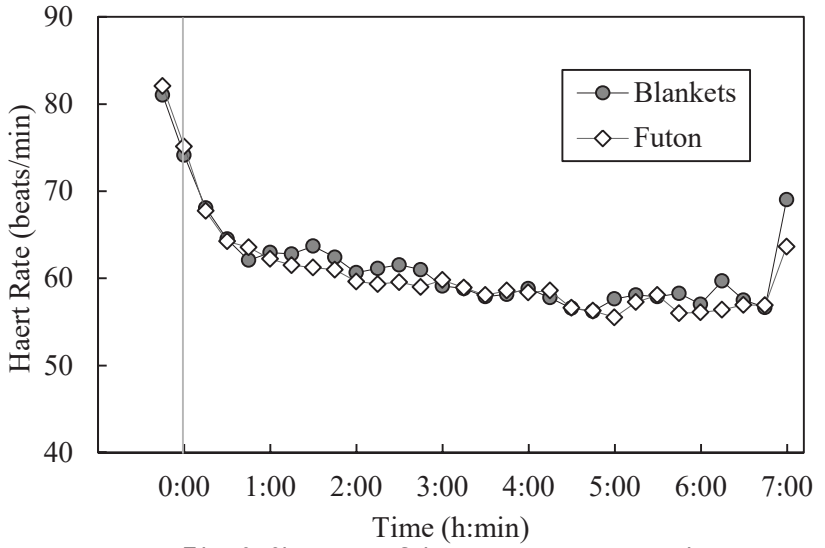

Fig. 9 Changes of heart rate averaged over 15 minute intervals.

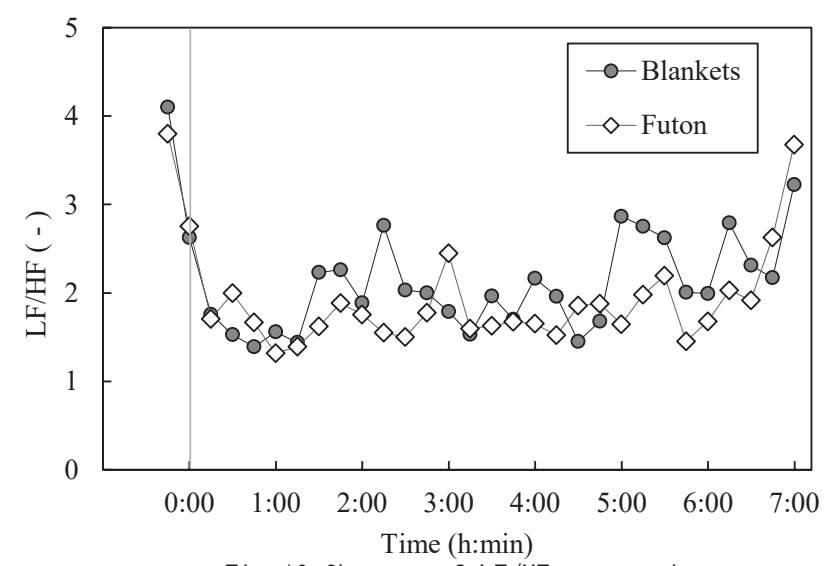

Fig. 10 Changes of LF/HF averaged over 15 minute intervals. 
2.0( $\mathrm{SD} \pm 0.6)$ 、布団が $1.8(\mathrm{SD} \pm 0.6)$ と毛布の方が高くなっていた。有 意な差はなかったものの、毛布使用時の低温環境下での就寝は布団 使用時に比べ、より心臟自律神経活動において交感神経の活性度が 上昇し、ストレス状態にあったと考えられる。

既往の研究 ${ }^{8)}$ では、就寝する温熱環境と、睡眠段階によって LF/HF の特徴が異なることが示唆されている。しかし、それは室温が高く なるほど LF/HF も高くなるという結果であり、本稿の研究結果とは 相対するものとなった。この不一致の結果については、測定方法や 比較方法の違いなど今後さらに詳細に検討する必要がある。本研究 では、同一の低温環境下での就寝時の比較を行っているため、冬季 の寒冷な環境では、より寝具を充実させ、十分な寝床内気候および 寝具の断熱性能を確保することが自律神経活動への悪影響を少なく できると考察できる。また、今回、寝具と人体との密着性や接触感、 さわり心地のような触覚に関わる自律神経活動を分離して測定する ことができなかった。今後は、それらについての測定法も検討し、 避難所での寝具に関わる要件について考慮して解明を続ける必要が あると考えられる。限られた資源の準備状況である避難所において も睡眠を損なわないような、ストレスを軽減できるような就寝環境 について検討し、提案していきたい。

\section{4. まとめ}

本研究では、冬季に本学体育館内武道場にて避難所を想定し、災 害救助用毛布 4 枚と段ボール製パーティションによって就寝する睡 眠環境と通常の布団 1 組によって就寝する睡眠環境の 2 条件を設定 し、寒冷環境下の避難所で人が睡眠した際の生理反応一の影響を被 験者実験によって、明らかにすることを目的として研究を行った。

以下に得られた知見を述べる。

1) 各睡眠変数を災害救助用毛布と通常布団を使用した場合で比較 したところ、有意な違いを確認できなかった。しかし、緊急避難 時を想定して、1 夜目の結果だけで比較したところ、災害救助用 毛布の方が中途覚醒時間は増加し、睡眠時間が減少して、結果と して睡眠効率が低下し、通常布団で就寝した場合の睡眠に比べ、 有意水準 5\%で有意に睡眠が悪化していた。このことから、緊急 避難時に断熱性能が低い寝具を使って低温環境下で就寝すること は、睡眠を悪化させることが明らかになった。

2) 皮膚温および直腸温については、災害救助用毛布を使用した睡眠 時に末梢部皮膚温が睡眠中に大きく低下寸る傾向が確認され、平 均皮膚温が有意に低くなった。これは、寝具と人体との間に形成 される寝床内気候が低温であった影響と推察される。また、直腸 温の低下については 2 条件間で差が認められず、就寝中低下し続 けたため、使用する寝具の差ではなく、就寝する温熱環境に依存 している可能性を示唆していた。

3) 時間変動における心拍数および LF/HF に有意な差は確認できな かった。しかし、災害救助用毛布での睡眠は、通常布団よりも $\mathrm{LF} / \mathrm{HF}$ の変動が比較的大きく、 $\mathrm{LF} / \mathrm{HF}$ の平均值は、有意差はなか ったものの、災害救助用毛布を用いた睡眠において高かったこと が確認された。したがって、災害救助用毛布のような不十分な寝 具を用いて、低温環境下で就寝することは、心臟自律神経活動に 影響を及ぼし、LF/HF の值が高いためストレス状態にあったと推
察された。このことは末梢部皮膚温や平均皮膚温の有意な低下か らも推察される。

本研究は睡眠に問題のない健康な青年男性を被験者として採用し 日頃から使い慣れている武道場において睡眠実験を行った。しかし、 第一夜目は中途覚醒時間が増加し、睡眠時間が短くなり、睡眠効率 が低下した。このことは、突然災害から避難し、不安を抱えながら 見知らぬ人々と一緒に就寝する災害時を完全に反映しているとは言 えないが、場所と寝具が異なり、寝具の断熱性が不十分な場合には、 寒冷環境は睡眠に影響を与えていると考えられる。さらに高齢者な どの環境からの影響を受けやすい人を対象とした研究が必要である と考えられる。

また、避難所での睡眠に関わる寝具等の要件についても、健康を 維持するという観点で検討し研究を進めていく必要がある。

\section{謝辞}

本研究の一部は, 科学研究費補助金（16K01589, 代表 : 森郁恵） の助成を受けたものである。また、本研究を遂行するにあたり、協 力を頂いた研究室の皆様、被験者として参加して頂いた本学学生の 皆様に、深甚なる謝意を記します。

\section{参考文献}

1) Iino,Y. Kurabuchi,T. Ogasawara,T. and Yuasa,K.: Actual conditions of living environments in evacuative gymnasiums at off site, AIJ Journal of Technology and Design, Vol.18, No.40, pp.1009-1012, 2012.10 (in Japanese) 飯野由香里, 倉㴊隆，小笠原岳，湯浅梢：オフサイト避難所における生活 境の実態，日本建築学会技術報告集，第 18 巻，第 40 号, pp1009-1012, 2012.10

2) Haga,Y. Kim,J. and Mitsuhashi,N.: The actual condition and tendency of local facilities as specified refuge shelter in the mid Niigata prefecture earthquake 2004 -A case study of refuge shelters in the former Nagaoka city-, Journal of Architecture and Planning (Transactions of AIJ), Vol.73, No. 624, pp349-355, 2008.2 (in Japanese)

羽賀義之, 金俊豪, 三橋伸夫: 新潟中越地震における地域施設の指定避難 所としての使われ方の実態と傾向-旧長岡市の指定避難所を事例に-, 日本 建築学会計画系論文集, 第 73 巻, 第 624 号, pp.349-355, 2008.2

3) Igarasi,Y. and N,Siogai.: Termal environment of shelters after Niigata Chuetsuoki earthquake, 31th proceedings of symposium on Human - Environment System, pp.65-68, 2007.11 (in Japanese)

五十嵐百合子，塩谷奈緒子：新潟県中越沖地震における避難所の温熱環境, 第 31 回 人間・生活環境系シンポジウム報告集, pp.65-68, 2007.11

4) Hamada,H. Mori,T. and Minami,S. et al. : Investigation on thermal environment of evacuation facility in severe cold clime, Architectural Institute of Japan Hokkaido Branch Architectural Research Meeting, No.87, pp.235-238, 2014.6 (in Japanese)

浜田祐章, 森太郎, 南真一 他 6 名: 巌冬季における避難所の温熱環境調 查, 日本建築学会北海道支部研究報告集, No.87, pp.235-238, 2014.6

5) Roger J,Cole. Daniel F,Kripke. et al.: Automatic Sleep/Wake Identification From Wrist Activity, American Sleep Disorders Association and Sleep Research Socity, Sleep, Vol.15, No.5, pp.461-469, 1992

6) Okamoto.T, Mizutani.K, Shikanai.Y and Tsunoda.T,: The study about heat stress with the human physiological response under cold or hot indoor environment. (part1) The measurement about the human physiological response under the thermal environment that assumed the refuge to the gymnasium of the winter season, Technical papers of annual meetings, the Society of Heating, Air-conditioning and Sanitary Engineers of Japan, Kusatsu, pp.1983-1986 2008.8 (in Japanese)

岡本卓也，水谷国男，鹿内勇太，角田正：寒冷・暑熱室内環境下における 人体生理反応と熱ストレスに関する研究（その1）避難時を想定した冬 季の体育館内の温熱環境と人体生理反応に関する実測, 空気調和・衛生工 学会大会学術講演論文集, 草津, pp.1983-1986, 2008.8 
7) Tsuzuki,K. Okamoto-Mizuno,K. Mizuno,K. Ohshiro,Y.: Effects of low temperature on human sleep and thermoregulation using bedding in winter, The 10th International Conference on Environmental Ergonomics, pp.361-364, 2002.9

8) Okamoto-Mizuno,K. Tsuzuki,K. Mizuno,K. and Oshiro,Y.: Effects of low ambient temperature on heart rate variability during sleep in human, European Journal of Applied Physiology, Vol.105, No.2, pp.191-197, 2009.1

9) Mizuno,K. and Okamoto-Mizuno,K.: Actigraphically evaluated sleep on the days surrounding the Great East Japan Earthquake, Natural Hazards, Vol.72, No.2, pp.969-981, 2014.1

10) Mori,T. Sadaike,Y. Kuwabara,K. et al.: Thermal environment of housings and evacuation facilities in disaster under severe winter cold climate, AIJ Journal of Technology and Design, Vol.22, No.52, pp.1021-1026, 2016.10 (in Japanese)

森太郎, 定池祐季, 桑原浩平, 他 3 名: 寒冷地における厳冬季被災時の住 宅と避難所の温熱環境, 日本建築学会技術報告集, 第 22 巻, 第 52 号, pp.1021-1026, 2016.10

11) Pache,M. Kräuchi,K. Cajochen,C. Wirz-Justice,A. Dubler,B. Flammer,J. and Kaiser,HJ.: Cold feet and prolonged sleep-onset latency in vasospastic syndrome, Lancet, Vol.358, No.9276, pp.125-6, 2001.7
12) Mochizuki,Y. Maeda,K. Tsuzuki,K. Matsumoto,H. and Nabeshima,Y.: A study to examine the thermal environment on sleep and physiological responses in shelter-analogue settings, The Society of Heating, Air-Conditioning and Sanitary Engineers of Japan, Chubu Branch, No.18, pp29-32, 2017.3 (in Japanese)

望月要佑, 前田和毅, 都築和代, 松本博, 鍋島佑基,：避難所を想定した睡 眠環境が人の生理反応に及ぼす影響に関する研究，空気調和・衛生工学会 中部支部学術研究発表会論文集, 第 18 号, pp.29-32, 2017.3

13) Mochizuki.Y, Maeda.K, Kazuyo.T, Nabeshima.Y,: Thermal Environment and Sleep in Winter Shelter-Analogue Settings, IGNITE-AICCE17, 2017.8.

注

注 1）時定数を $0.01 \mathrm{G} / \mathrm{s}$ とし、0.1 秒間隔で時定数を超えたカウントの 1 分間 の合計がアウトプットされる。

注 2) 本稿で用いた平均皮膚温は手背の代わりに上腕、腹部の代わりに胸部 の皮膚温を用いて、算出を行っている。

注 3）毛布条件において、1 名（2 夜目）の睡眠変数の久測があったため、そ のデータについては取り扱わないものとする。

注 4）本稿は、既報である参考文献 ${ }^{12)}$, 13) に追加解析、修正、加筆したもので ある。また、参考文献 ${ }^{13)}$ においては、国際会議において口頭発表。現 時点で論文はまだ未公開である。 


\title{
A STUDY TO EXAMINE THE THERMAL ENVIRONMENT ON SLEEP AND PHYSIOLOGICAL RESPONSES IN SHELTER-ANALOGUE SETTINGS IN WINTER
}

\author{
Yosuke MOCHIZUKI ${ }^{* 1}$, Kazuki MAEDA ${ }^{* 1}$, Kazuyo TSUZUKI*2 \\ and Yuki NABESHIMA*3 \\ ${ }^{* 1}$ Grad. Student, Dept. of Arch. And Civil Eng., Toyohashi Univ. of Tech. \\ ${ }^{* 2}$ Prof., Dept. of Arch. And Civil Eng., Toyohashi Univ. of Tech., Ph.D. \\ *3 Assist. Prof., Dept. of Arch. And Civil Eng., Toyohashi Univ. of Tech., Dr.Eng.
}

In recent years, many large-scale disasters have occurred and life in evacuation shelters has been a subject of much focus. However, since these facilities are where an insufficient thermal environment is assumed, they're thought to have an adverse effect on the health of evacuated people. In previous research, environmental factors were investigated. However, there's no research to clarify the influence on the human body when a person is sleeping in a shelter during the winter season. Also, until now, research on sleep in summer has been actively conducted, but in winter sleep, the actual state of sleep in a low temperature environment has never been elucidated due to the influence of bedding etc. Therefore, in this research, we aimed to clarify this influence on the physiological responses of subjects. Accordingly, we set up two conditions for a sleeping environment assuming a shelter on the 2nd floor of the gymnasium at the Toyohashi University of Technology and performed sleep experiments using blankets for disaster relief (Blankets:1.3clo) and a pair of ordinary futons (Futon:3.1clo) with human subjects. When using four blankets for disaster relief, additional partitions made by cardboard surround the sleeping human. Moreover, the subjects slept wearing their own clothing such as T-shirts, sweatshirts, hoodies, underpants, sweatpants, pants, and two pairs of socks (0.76clo) during the sleep. The air temperature, relative humidity, and air velocity were continuously measured around the human body and outside the gymnasium. The skin temperature at seven sites on the human body, rectal temperature, sleep variables, bedding microclimate temperature and humidity, as well as heart rate were continuously measured and recorded during the experiment. The subjects slept for seven hours.

The thermal environment inside the gymnasium was a very cold environment because it was about $3.6^{\circ} \mathrm{C}$ at dawn. The average bedding microclimate temperature was $23.8^{\circ} \mathrm{C}$ for Blankets, $22.2^{\circ} \mathrm{C}$ for Futon, and the average bedding microclimate humidity was $33.8 \%$ for Blankets and $37.7 \%$ for Futon, and Blankets were low for both bed temperature and humidity. It can be confirmed that the Blankets used in this study were thermally inferior to the Futon as shown in insulation. Average Sleep Efficiency Index (SEI) was 86\% in Blankets and 91\% in Futon. However, we couldn't confirm a significant difference in all sleep variables for the t-test $(\mathrm{P}<0.05)$. Furthermore, when comparing the sleep variables for the first night assuming an emergency evacuation, a significant difference was confirmed between SEI, wakefulness time, and sleeping time $(\mathrm{P}<0.05)$. The SEI and sleeping time decreased significantly and wakefulness increased significantly using Blankets compared to them using Futon. These results have revealed that sleep is disturbed when going to bed in a low temperature environment with insufficient insulation bedding upon an emergency evacuation. Regarding skin temperature, the mean skin temperature was higher in Futon than Blankets in all time zones, and it was confirmed that there was a significant difference between the two cases $(\mathrm{P}<0.05)$. In addition, sleeping with insufficient bedding showed a tendency for the skin temperature at the distal end to decrease greatly. There were no significant differences in heart rate and time fluctuation of LF/HF. However, the average value of LF/HF was higher in sleeping using Blankets. The higher LF/HF might show that sleep using Blankets is more stressful than that using Futon.

Therefore, sleeping in a low temperature environment using insufficient bedding such as a disaster blanket significantly lowers the mean skin temperature by decreasing skin temperature at the distal end and affects cardiac autonomic nervous activity. Especially, regarding the first night of an emergency evacuation, it became clear that even in healthy young boys, sleep was disturbed in low temperature environments. 